\title{
Review of Characteristics of Alnus Glutinosa Stands Quality According to Forest Ttypes and Ages
}

\author{
Ziedonis Miklašēvičs \\ Rezekne Academy of Technologies \\ State Stock Company “Latvijas Valsts Meži” (Latvia’s State Forests) \\ Rēzekne, Latvia \\ Email: (Ziedonis Miklašēvičs): z.miklasevics@lvm.lv
}

\begin{abstract}
Due to the interest in Alnus glutinosa as the plantation species has increasesed in Latvia during last years, a structural unit "LVM Sēklas un stādi" of State Stock Company "Latvijas Valsts Meži” (Latvia's State Forests) offers to the local market Alnus glutinosa bare root seedlings with an advanced root system obtained from Alnus glutinosa seeds growed in planting such selected seedlings in cutovers and for land reforestation theorectically will allow the land owner to increase the value of forest and the profit from its management. Practically, this prospects should be evaluated from the perspective of forest health.

Therefore, the purpose of this study were to: (1) estimate the incidence of heart colouring and stem decay in Alnus glutinosa stands in different forest types and ages, (2) identify and measure heart colouring area /heartwood hard rot stage area diameter and soft rot stage area diameter/ cavity diameter of the stumps, (3) evaluate the relationships between stand species composition (forest types) and Alnus glutinosa stands age on heart colouring/heartwood hard rot stage and soft rot stage/cavity incidence, (4) by analysing the results to work out the recommendations to improve the forest managment in forest stands where Alnus glutinosa stands from plantations are growing.
\end{abstract}

Keywords - Alnus glutinosa, Dryopterioso-caricosa, Myrtillosa, Myrtillosaturf.mel, Dryopterioso-caricosa, Oxalidosa, Myrtilloso-sphagnosa, Oxalidosa turf.mel.

\section{INTRODUCTION}

Stands of black alder (Alnus glutinosa (L.),Gaertn.) comprise $5.1 \%$ of the total forest area of Latvia. Alnus glutinosa typicaly grows on wet petlands, usually comprising pure stands or stands mixed with Alnus incana (L.) Moench., Bertula spp., Populus tremula L. and Picea abies (L.) Karst. [1], [16]. Specific characteristics of this treee species are frost and waterlogging tolerance, a strong root system that penetrates both vertically and horizontally, adaption to various soil conditions and ability to fix nitrogen in symbioyic root nodules with bacteria in the genus Frankia [1], [3]. The root system is adapted to very wet soils. Many strong, vertically growing, sinker roots ancor the tree on riverbanks, and they are able to penetrate deeply into wet and anaerobic soils reaching almost $5 \mathrm{~m}$ deep [9].

Three main site types where Alnus glutinosa grows can be identified [5], [6] in relation to the type of water supply are:

- Marshy sites that have waterlogged subsoil throughout the year. On these, Alnus glutinosa forms pure stands owing to its physiological adaptions that allow it to grow in anaerobic soils.

- $\quad$ Riverside sites in which the soil in the rooting zone is well aerated during the growing season. On these, Alnus glutinosa is often mixed with species that are adapted to alluvial sites (AlnoPadion community).

- Plateau sites which high soil moisture contents where the stand is dominated by other species that are more competitive (Carpinion community).

Alnus glutinosa is regarded a short living tree species, starting to die out naturally at about 60 years of age under Central European conditions [18]. However, depending on the region and growth conditions, the species might reach age of 100-160 years [5]. Alnus glutinosa is usually attacked by a heartwood rot at the age of 50-70 years [5]. Some authors noted that Alnus glutinosa wood quality declines after 60-70 years because of heartwood rot [4], [17]. According to investigations made in Bavaria [7] the beginning of the phenomenon at about age 50. According to the results of investigaton [1] made in Latvia, the 
frequency of stem decay and heart colouring of 51-84 year old Alnus glutinosa stands are sequental "Table 1 ”.

TABLE 1 CHARACTERISTICS OF ALNUS GLUTINOSA STEM QUALITY

\begin{tabular}{cclcc}
\hline Age, years & Species composition ( \%) & Forest site type & Sampled trees, no. & Decayed stems (\%) \\
\hline 51 & 100 Alnus glutinosa & Mercurialiosa & 100 & 98 \\
74 & 80 Alnus glutinosa +20 & Filipendulosa & 100 & 82 \\
& $\quad$ Alnus incana & & & \\
76 & $\begin{array}{c}\text { 60 Alnus glutinosa }+30 \\
\text { Alnus incana }+10\end{array}$ & Oxalidosa turf. & 150 & 53 \\
& $\quad$ Picea abies & & & 78 \\
84 & 80 Alnus glutinosa +20 & Oxalidosa turf. & 100 & 75 \\
\hline
\end{tabular}

According to investigations [10] the frequency of heartwood rot differs with site but diagnosis from external characteristics is unreliable.

Nowadays Alnus glutinosa is becoming increasly important as a plantation species. Aside from commeercial forestry, this tree species is important for riparian ecosystems and their biodiversity, providing habitants for specific wetland flora and fauna and stabilising riverbanks [1], [15].

If Alnus glutinosa is planted in a cutover where a heartwood rot has already been established [5], there will be no positive effect, as the young trees will become infected when their roots contact with the roots of the rotten stumps [13].

It is believed that deciduous tree in pure stands are generally resistant to Heterobasidion root rot. On the other hand, the results of studies performed in Lithuania show that Bertula stands planted in previously severely affected areas of $H$. annosum (Pinus sylvestris) is also infected with $H$. annosum [11]. However, it is possible that no suitable planting material has been selected in this case [8].

The vegetative method plays a very important role in the propagation of many deciduous tree species. Alnus glutinosa has great strain-healing abilities. A forest derived from seeds differs in many biological characteristics from a forest derived from coppice. In large forest stands, trees are often taller at the end of their lives compared to trees growed brom coppice. For example, oak forests continue to grow intensively until the age of 120150 years, live 300-400 years and reach a height of 30-40 $\mathrm{m}$. Oak shoots grow intensively for $70-80$ years, live for 150-200 years and reach a height of 20-30 m.

\section{STUDY GOAL}

The goal of this study was to synthesize the existing experience and knowledge about the silviculture of Alnus glutinosa on suitable sites in relation to the production of high quality and valuable timber and to work out the
The third important difference between a large forest and a coppice is that the wood structure of a large forest is more even and correct than that of a coppice tree. Big forest trees differ much more radically from coppice trees in that the carcasses damage trees much less in stand stands than in coppice trees. In stands formed vegetatively, the stems and roots of the mother trees gradually die. Through the parts of the dying roots, the fungal filaments penetrate the coppice and develop freely in the new generation of forest.

Because of that foresters must ensure the regeneration of the forest with seeds, seedlings, not coppice [13].

The early stage of forestry is cruical for successful and sustainable forest managment. One third of the reforested forest in Latvia is regenerated by planting with different kinds of tree seedings. The success of forest regeneration by planting depends on correctly prepared soil and chouice of the right seeding material. Reforestation by Alnus glutinosa in Joint Stock Company "Latvia State Forests” ( LVM ) have been conducting by bare roots, containerized and with improved root system. The main aim in forestry is to achieve higher tree seeding establishment and promote their growth and improve fixation in soil. Practically, this procpects should be evaluated from the perspective of forest health.

In order to ensure and improve the ecological stability of forests, the ability to adapt to various pathogenic microorganisms and resistance to stress factors caused by anthropogenic effects, the territory of Latvia is divided into two regions for (Alnus glutinosa Gaertn.) reforestation. Seedlings obtained from clone seeds in West region "Fig. 2", “Table 4" can be planted only in West region of Latvia "Fig. 2”. The same methodology applies to East and North regions.

recommendations to improve the forest managment in forest stands where Alnus glutinosa stands from plantations are growing.

The following objectives were set to achieve the study goal: 
- $\quad$ To identify the origin of the clones in the West region of Latvia.

- To estimate the incidence of heart colouring and stem decay in Alnus glutinosa stands in different forest types and ages in all regions of Latvia.

- To identify and measure the diameter of heart colouring and stem decay area.

- To evaluate the relationships between stand species composition (forest types) and Alnus glutinosa stands age on heart colouring/heartwood rot incidence.

\section{MATHERIALS AND METHODS}

\subsection{Field Measurements.}

- Sampling stumps of Alnus glutinosa in different forest type and age class felling areas after commercial thinning and final felling for estimating the frequency of decay and heart colouring.

- Measuring the diameters of the stumps, the diameters of heart colouring areas, and diameters of heartwood rot areas according to the scheme “Fig. 1".

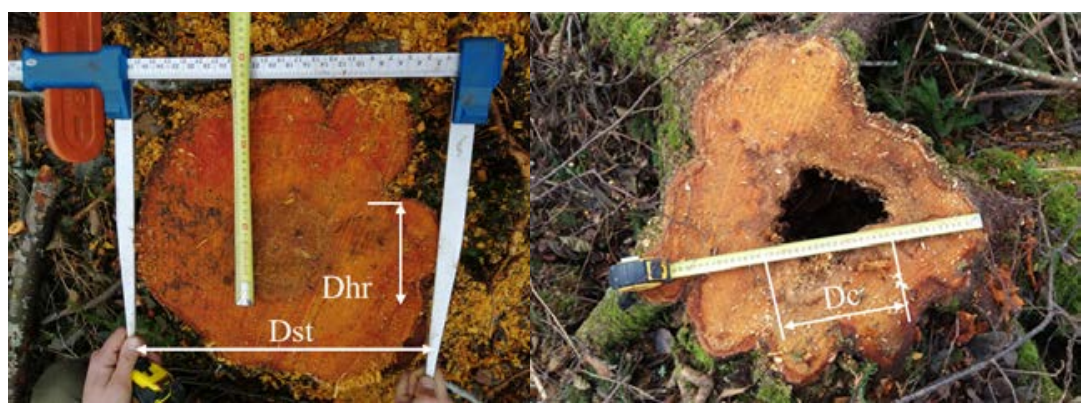

Fig.1. Dst- diameter of the stump; Dhr- Heart colouring area /Heartwood hard rot stage area diameter; Dc -Heartwood soft rot stage area diameter/ Cavity diameter

\subsection{Statistical Analyses.}

The sequental data were collected and analysed:

- Block area-Forest block-Forest compartment; Area (ha) ; Stock nr; Average tree $\left(\mathrm{m}^{3}\right)$; Stock $\left(\mathrm{m}^{3}\right)$; County; Coordinates X/Y; Forest type; Age class; Age decade; Species composition; Sampled stumps (pcs.); Decayed (Heartwood soft rot/ Cavity) stems(\%); Stump diameter (mm)/ Average/Median/Stdev; Heart colouring area diameter/Heartwood hard rot stage diameter (mm); Average/Median/Stdev; Heartwood soft rot stage diameter/Cavity diameter(mm) Average/Median/Stdev

\section{RESULTS AND DISCUSIONS}

In order to ensure and improve the ecological stability of forests, the ability to adapt to various pathogenic microorganisms and resistance to stress factors caused by anthropogenic effects, the territory of Latvia is divided into regions of origin of Alnus glutinosa, which must be observed in the processes of reforestation [12].

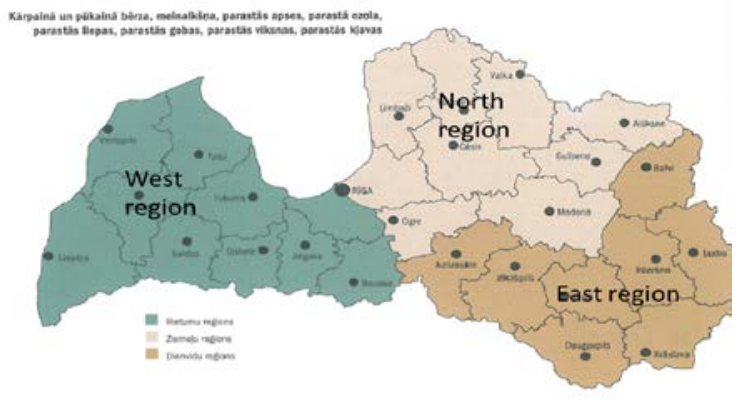

Fig.2. Regions of origin of Alnus glutinosa [12]
The Latvian State Forest Research Institute "Silava" has confirmed that the identification of 50 clones (Alnus glutinosa Gaertn.) of Platene (West region of Latvia) seed plantations and operations has been done with molecular passporting methods that ensure the acquisition of these plants in the forest reproductive material identification to be at the stage of production, trade or use. The results of the identification are given in "Table 2 ". 
TABLE 2 MOLECULAR PASSPORT OF THE CLONES

\begin{tabular}{|c|c|c|c|c|c|c|c|c|c|c|c|c|c|c|c|c|c|c|c|}
\hline \multicolumn{2}{|c|}{ Clone, no. Sample, no. } & \multicolumn{18}{|c|}{ Makers } \\
\hline 1 & 43 & 189 & 189 & 335 & 340 & 247 & 247 & 116 & 116 & 233 & 233 & 242 & 246 & 151 & 157 & 230 & 247 & 190 & 190 \\
\hline 2 & 10 & 189 & 193 & 344 & 348 & 247 & 247 & 116 & 120 & 225 & 233 & 242 & 256 & 157 & 157 & 247 & 247 & 132 & 134 \\
\hline 3 & 21 & 0 & 0 & 337 & 344 & 247 & 247 & 116 & 118 & 225 & 236 & 246 & 246 & 151 & 187 & 226 & 247 & 0 & 0 \\
\hline 4 & 28 & 0 & 0 & 318 & 346 & 247 & 247 & 116 & 118 & 225 & 233 & 248 & 248 & 157 & 157 & 0 & 0 & 0 & 0 \\
\hline 5.-53. & & & & & & & & & & & & & & & & & & & \\
\hline
\end{tabular}

Reforestation by Alnus glutinosa in LVM in West region "Fig. 2" have been conducting by bare roots, containerized and with improved root system. The scheme of manufacturing of seedings with improved root system is given "Fig. 3."

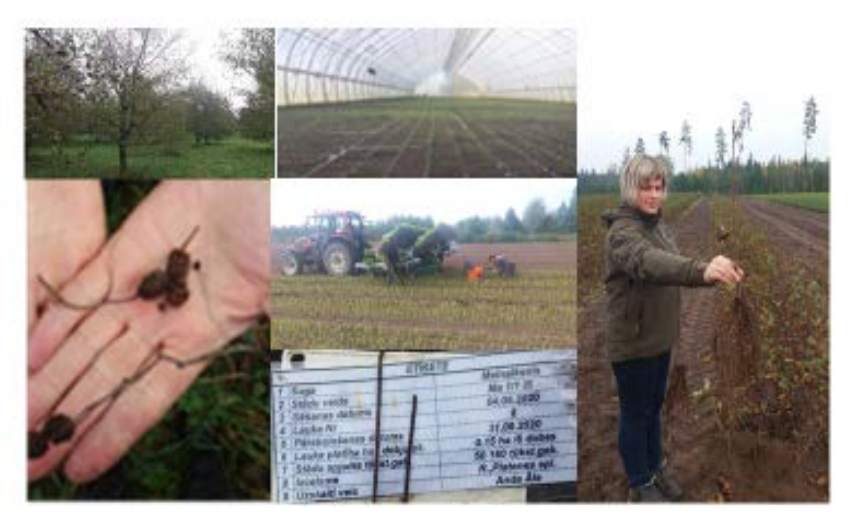

Fig. 3. The scheme of manufacturing of seedings with improved root system

Reforestation by Alnus glutinosa in LVM in West, North and East region in 2021 will be conducted according to the plan of growing seedling “Table 3. ”

\begin{tabular}{ccccc}
\multicolumn{5}{c}{ TABLE 3 PLAN OF GROWING SEEDLING } \\
\hline Plantation & Region & Plan in 2020 (pcs.) & Sown in 2020 (pcs.) & Realization plan in 2021(pcs.) \\
\hline Strenči & North & 250000 & 479830 & 180000 \\
Podinii & East & 693450 & 1729450 & 485415 \\
Mazsili & West & 328300 & 328300 & 229810 \\
\hline
\end{tabular}

The origin of Alnus glutinosa clones for refrostation in West region were obtained in 2002. The characteristic of origin of the clones are given in "Table 4. "

\begin{tabular}{|c|c|c|c|c|c|}
\hline \multirow{2}{*}{$\begin{array}{c}\text { Parameter } \\
\begin{array}{c}\text { Block area-Forest block-Forest } \\
\text { compartment }\end{array}\end{array}$} & \multicolumn{5}{|c|}{ Data } \\
\hline & 703-204-14 & 703-204-15 & $703-214-8$ & 703-204-2 & $703-214-7$ \\
\hline Area (ha) & 2.39 & 4.27 & 8.8 & 2.96 & 2.94 \\
\hline County & \multicolumn{5}{|c|}{ Dundaga } \\
\hline Age (Age decade) years & $78(8)$ & $98(10)$ & $88(9)$ & $98(10)$ & $73(8)$ \\
\hline Species composition & $\begin{array}{c}9 \text { Alnus glutinosa } 1 \text { Bertula } \\
78+\text { F.excelsior } \\
78+\text { P.Abies } 71 \\
\end{array}$ & $\begin{array}{c}10 \text { Alnus glutinosa } \\
98+\text { Bertula } 98 \\
\quad+P . \text { Abies } 91 \\
\end{array}$ & $\begin{array}{c}8 \text { Alnus glutinosa } \\
2 \text { Bertula } 88+ \\
\text { P.Abies } 88 \\
\end{array}$ & $\begin{array}{c}10 \text { Alnus } \\
\text { glutinosa } 98 \\
+ \text { Bertula } 98 \\
\end{array}$ & $\begin{array}{c}10 \text { Alnus } \\
\text { glutinosa } 73 \\
+ \text { Bertula } 91+ \\
\end{array}$ \\
\hline Specie & & 04-Bertula & & & \\
\hline Age (years) & 78 & & 88 & & \\
\hline Height (m) & 26 & & 27 & & \\
\hline Diameter (cm) & 27 & & 29 & & \\
\hline Basal area $\left(\mathrm{m}^{2}\right)$ & 2 & & 6 & & \\
\hline Stock $\left(\mathrm{m}^{3} / \mathrm{ha}\right)$ & 23 & & 72 & & \\
\hline Specie & $06-$ & Alnus glutinosa & & & \\
\hline Age (years) & 78 & & 88 & & \\
\hline Height (m) & 26 & & 26 & & \\
\hline Diameter (cm) & 30 & & 31 & & \\
\hline Basal area $\left(\mathrm{m}^{2}\right)$ & 25 & & 26 & & \\
\hline Stock (m³/ha ) & 309 & & 321 & & \\
\hline
\end{tabular}


Environment. Technology. Resources. Rezekne, Latvia Proceedings of the $13^{\text {th }}$ International Scientific and Practical Conference. Volume 1, 170-177

In order to estimate the incidence of heart colouring and stem decay in Alnus glutinosa stands in different forest types and ages, to identify and measure the diameter of heart colouring and stem decay area and to evaluate the relationships between stand species composition (forest types) and Alnus glutinosa stands age on heart colouring/heartwood rot incidence, during 2020-2021, incidence of butt rot in Alnus glutinosa stands and the presence of fungi responsible for it were investigated

TABLE 5 CHARACTERISTICS OF INVESTIGATED FOREST SITE TYPES

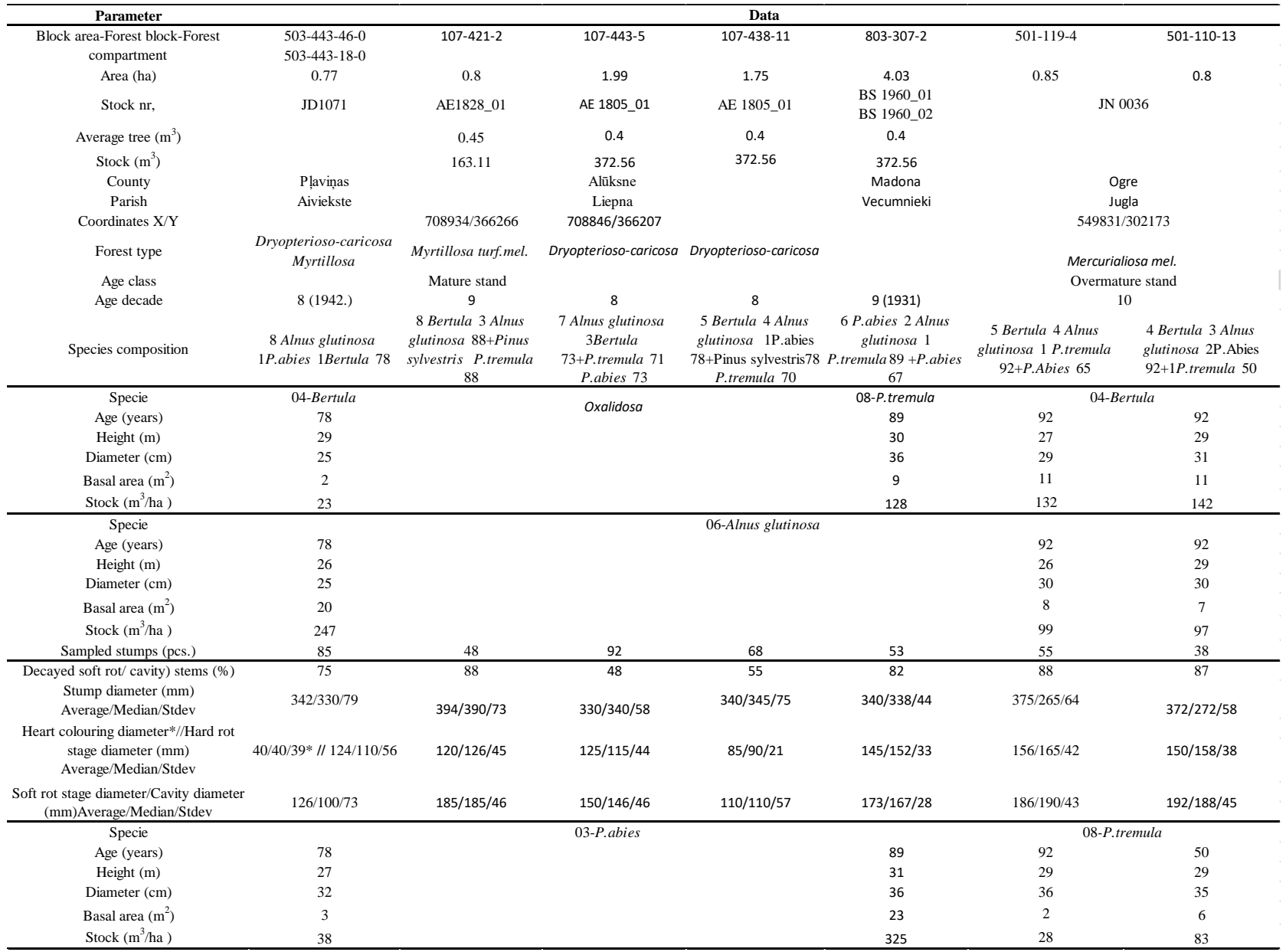




\begin{tabular}{|c|c|c|c|c|c|c|}
\hline \multirow{2}{*}{$\begin{array}{c}\text { Parameter } \\
\text { Block area-Forest block-Forest compartment }\end{array}$} & \multicolumn{6}{|c|}{ Data } \\
\hline & $803-305-23$ & $807-71-4$ & $202-454-8$ & 202-453-29 & $313-42-25$ & $312-228-18$ \\
\hline Area (ha) & 2 & 2.32 & 1.54 & 1.01 & 1.84 & 1.96 \\
\hline Stock nr, & AA2323 & BS 1933 & HT1840_01 & HT1906_01 & BT 2007_01 & BT 2020_01 \\
\hline Average tree $\left(\mathrm{m}^{3}\right)$ & 0.6 & 0.44 & 0.79 & 0.6 & 0.72 & 0.1 \\
\hline Stock $\left(\mathrm{m}^{3}\right)$ & 795.57 & 292 & 512.4 & 262.5 & 367.8 & 91.14 \\
\hline County & Madona & Kārsava & Renda & Renda & Svente & Svente \\
\hline Coordinates $\mathrm{X} / \mathrm{Y}$ & 661455/282037 & $697466 / 31613$ & $396397 / 321503$ & $398896 / 322313$ & 668075/183534 & 658119/179698 \\
\hline Forest type & Oxalidosa & Myrtilloso-sphagnosa & Oxalidosa & Myrtilloso-sphagnosa & Oxalidosa turf.me & Dryopterioso-caricosa \\
\hline Age class & & & Mature stand & & & Middle age stand \\
\hline Age decade & $8(1946)$ & 8 & 8 & 9 & 9 & 3 \\
\hline Species composition & $\begin{array}{l}8 \text { Alnus glutinosa } \\
\text { 1P.tremula } 1 \text { Bertula } 74 \\
\quad+\text { P.Abies } 56\end{array}$ & $\begin{array}{c}6 \text { Bertula } 1 \text { Alnus } \\
\text { glutinosa } 2 \\
\text { P.Sylvestris 1P.Abies } \\
74+P . \text { Abies } 63\end{array}$ & $\begin{array}{l}4 \text { Bertula } 4 \text { P.Abies } 1 \\
\text { P.Sylvestris } 1 \text { Alnus } \\
\text { glutinosa }\end{array}$ & $\begin{array}{c}4 \text { Bertula } 2 \text { Alnus } \\
\text { glutinosa } 2 \text { P.Sylvestris } 1 \\
\text { P.Abies } 861 \text { Alnus } \\
\text { glutinosa } 66+\text { Bertula } 66\end{array}$ & $\begin{array}{l}4 \text { Alnus glutinosa } \\
2 \text { Bertula } 2 \\
\text { P.Abies } \\
\text { 1P.tremula } 89\end{array}$ & $\begin{array}{l}\text { 4Alnus glutinosa } \\
\text { 3Bertula } 28 \\
\text { +P.tremula28 }\end{array}$ \\
\hline Specie & \multicolumn{6}{|c|}{ 04-Bertula } \\
\hline Age (years) & 74 & 74 & 71 & 86 & & 28 \\
\hline Height (m) & 25 & 23 & 25 & 23 & & 16 \\
\hline Diameter (cm) & 29 & 25 & 25 & 28 & & 15 \\
\hline Basal area $\left(\mathrm{m}^{2}\right)$ & 3 & 14 & 15 & 7 & & 4 \\
\hline Stock $\left(\mathrm{m}^{3} / \mathrm{ha}\right)$ & 33 & 144 & 167 & 72 & & 31 \\
\hline Specie & \multicolumn{6}{|c|}{ 06-Alnus glutinosa } \\
\hline Age (years) & 74 & 74 & 71 & 86 & & 28 \\
\hline Height (m) & 26 & 21 & 21 & 23 & & 16 \\
\hline Diameter $(\mathrm{cm})$ & 27 & 25 & 25 & 27 & & 18 \\
\hline Basal area $\left(\mathrm{m}^{2}\right)$ & 30 & 2 & 6 & 4 & & 9 \\
\hline Stock $\left(\mathrm{m}^{3} / \mathrm{ha}\right)$ & 371 & 20 & 60 & 44 & 120 & 71 \\
\hline Sampled stumps (pcs.) & 50 & 35 & 48 & 56 & 32 & 42 \\
\hline Decayed (soft rot/ cavity) stems(\%) & 88 & 83 & 79 & 67 & 92 & 4 \\
\hline Stump diameter (mm)/ Average/Median/Stdev & $317 / 310 / 59$ & $341 / 320 / 71$ & $315 / 295 / 65$ & $335 / 315 / 78$ & $325 / 331 / 69$ & $200 / 195 / 38$ \\
\hline $\begin{array}{l}\text { Heart colouring diameter/Hard rot stage } \\
\text { diameter }(\mathrm{mm}) \text { Average/Median/Stdev }\end{array}$ & $152 / 160 / 30$ & $133 / 140 / 39$ & $115 / 135 / 42$ & $142 / 155 / 42$ & & \\
\hline $\begin{array}{c}\text { Soft rot stage diameter/Cavity diameter } \\
(\mathrm{mm}) \text { Average/Median/Stdev }\end{array}$ & $167 / 160 / 27$ & $138 / 145 / 37$ & $108 / 120 / 40$ & $145 / 150 / 40$ & $152 / 149 / 48$ & \\
\hline Specie & 08-P.tremula & 01-P.sylvestris & 03-P.abies & 01-P.sylvestris & & \\
\hline Age (years) & 74 & 74 & 71 & 86 & & \\
\hline Height (m) & 26 & 26 & 24 & 26 & & \\
\hline Diameter $(\mathrm{cm})$ & 44 & 27 & 28 & 32 & & \\
\hline Basal area $\left(\mathrm{m}^{2}\right)$ & 5 & 6 & 10 & 6 & & \\
\hline Stock $\left(\mathrm{m}^{3} / \mathrm{ha}\right)$ & 62 & 71 & 114 & 71 & & \\
\hline Specie & & & & 03-P.abies & & \\
\hline Age (years) & & & & 86 & & \\
\hline Height (m) & & & & 23 & & \\
\hline Diameter (cm) & & & & 27 & & \\
\hline Basal area $\left(\mathrm{m}^{2}\right)$ & & & & 6 & & \\
\hline Stock $\left(\mathrm{m}^{3} / \mathrm{ha}\right)$ & & & & 66 & & \\
\hline Specie & & & & 06-Alnus glutinosa & & \\
\hline Age (years) & & & & 66 & & \\
\hline Height (m) & & & & 20 & & \\
\hline Diameter (cm) & & & & 23 & & \\
\hline Basal area $\left(\mathrm{m}^{2}\right)$ & & & & 2 & & \\
\hline Stock $\left(\mathrm{m}^{3} / \mathrm{ha}\right)$ & & & & 19 & & \\
\hline
\end{tabular}

Surveyed were altogether 13 felling areas in Vidusdaugava, Dienvidkurzeme, Zemgale, Ziemeḷlatgale, Dienvidlatgale, Austrumvidzemes Forest Districts the results of the investigation are given in
“Table 5”. Characteristics data of investigated Alnus glutinosa stands are given in "Table 6 ." 
Environment. Technology. Resources. Rezekne, Latvia Proceedings of the $13^{\text {th }}$ International Scientific and Practical Conference. Volume 1, 170-177

TABLE 6

CHARACTERISTICS OF INVESTIGATED ALNUS GLUTINOSA STANDS

\begin{tabular}{|c|c|c|c|c|c|c|}
\hline $\begin{array}{c}\text { Age (Age } \\
\text { decade), years }\end{array}$ & Species composition ( \%) & Forest site type & Sampled stumps, no. & Decayed stems (\%) & $\begin{array}{c}\text { Stump } \\
\text { diameter } \\
\text { Average }(\mathbf{m m}) \\
\end{array}$ & $\begin{array}{l}\text { Soft rot stage } \\
\text { /Cavity diameter } \\
\text { Average (mm) }\end{array}$ \\
\hline $28(3)$ & $\begin{array}{c}4 \text { Alnus glutinosa } 3 \text { Bertula } 28 \\
+ \text { P.tremula } 28\end{array}$ & Dryopterioso-caricosa & 42 & 4 & 200 & \\
\hline $74(8)$ & $\begin{array}{c}8 \text { Alnus glutinosa 1P.tremula } 1 \\
\text { Bertula } 74+P \text {.Abies } 56\end{array}$ & Oxalidosa & 50 & 88 & 317 & 167 \\
\hline $74(8)$ & $\begin{array}{c}6 \text { Bertula } 1 \text { Alnus glutinosa } 2 \\
\text { P.Sylvestris 1P.Abies } 74+P . \text { Abies } \\
63\end{array}$ & Myrtilloso-sphagnosa & 35 & 83 & 341 & 138 \\
\hline $79(8)$ & $\begin{array}{c}4 \text { Bertula } 4 \text { 4P.Abies } 1 \text { P.Sylvestris } 1 \\
\text { Alnus glutinosa }\end{array}$ & Oxalidosa & 48 & 79 & 315 & 108 \\
\hline $78(8)$ & $\begin{array}{c}8 \text { Alnus glutinosa } 1 \text { P.abies } \\
\text { 1Bertula } 78\end{array}$ & $\begin{array}{c}\text { Dryopterioso-caricosa } \\
\text { Myrtillosa }\end{array}$ & 85 & 75 & 342 & 126 \\
\hline $73(8)$ & $\begin{array}{l}7 \text { Alnus glutinosa 3Bertula } \\
73+\text { P.tremula } 71 \text { P.abies } 73\end{array}$ & Dryopterioso-caricosa & 92 & 48 & 330 & 150 \\
\hline \multirow[t]{2}{*}{$78(8)$} & $\begin{array}{c}5 \text { Bertula } 4 \text { Alnus glutinosa } \\
\text { 1P.abies } 78+\text { Pinus sylvestris78 } \\
\text { P.tremula } 70\end{array}$ & Dryopterioso-caricosa & 68 & 55 & 340 & 110 \\
\hline & & & Average & 69 & 332 & 133 \\
\hline $86(9)$ & $\begin{array}{c}4 \text { Bertula } 2 \text { Alnus glutinosa } 2 \\
\text { P.Sylvestris } 1 \text { P.Abies } 861 \text { Alnus } \\
\text { glutinosa } 66+\text { Bertula } 66\end{array}$ & Myrtilloso-sphagnosa & 56 & 67 & 335 & 145 \\
\hline 89 (9) & $\begin{array}{l}4 \text { Alnus glutinosa } 2 \text { Bertula } 2 \\
\text { P.Abies 1P.tremula } 89\end{array}$ & Oxalidosa turf.mel. & 32 & 92 & 325 & 152 \\
\hline $88(9)$ & $\begin{array}{l}8 \text { Bertula } 3 \text { Alnus glutinosa } \\
\text { 88+Pinus sylvestris P.tremula } 88\end{array}$ & Myrtillosa turf.mel. & 48 & 88 & 394 & 185 \\
\hline \multirow[t]{2}{*}{89 (9) } & $\begin{array}{l}6 \text { P.abies } 2 \text { Alnus glutinosa } 1 \\
\quad \text { P.tremula } 89+\text { P.abies } 67\end{array}$ & Oxalidosa & 53 & 82 & 340 & 173 \\
\hline & & & Average & 81 & 345 & 164 \\
\hline $92(10)$ & $\begin{array}{l}5 \text { Bertula } 4 \text { Alnus glutinosa } 1 \\
\text { P.tremula 92+P.Abies } 65\end{array}$ & Mercurialiosa mel. & 55 & 88 & 375 & 186 \\
\hline \multirow[t]{2}{*}{$92(10)$} & $\begin{array}{l}4 \text { Bertula } 3 \text { Alnus glutinosa } \\
\text { 2P.Abies } 92+1 \text { P.tremula } 50\end{array}$ & & 38 & 87 & 372 & 192 \\
\hline & & & Average & 88 & 373 & 188 \\
\hline
\end{tabular}

\section{V.CONCLUSIONS AND RECOMENDATIONS}

1. To ensure the quality of Alnus glutinosa wood, reforestation must be carried out with seeds, seedlings, not coppice.

2. In the processes of reforestation the regions of origin of Alnus glutinosa must be observed.

3. The main factor influencing the quality of wood is the age of the stems of Alnus glutinosa. The highest quality wood is up to 30 -year-old stems.

4. When harvesting has been managed in stands older than 70 years, the proportion of decayed stems exceeds 69\%, heartwood rot diameter reaches 133 $\mathrm{mm}$ at an average stump diameter of $332 \mathrm{~mm}$.

5. When harvesting has been managed in stands older than 80 years, the proportion of decayed stems exceeds 81\%, heartwood rot diameter reaches 164 $\mathrm{mm}$ at an average stump diameter of $345 \mathrm{~mm}$.

6. When harvesting has been managed in stands older than 90 years, the proportion of decayed stems exceeds 88\%, heartwood rot diameter reaches 188 $\mathrm{mm}$ at an average stump diameter of $373 \mathrm{~mm}$.

\section{REFERENCES}

[1] N. Arhipova, T. Gaitnieks, J. Donis, and J. Stenlid, "Heart rot and associated fungi in Alnus glutinosa stands in Latvia". Scandinavian Journal of Forest Research, 27 : 2012, pp. 327-336.

[2] N. Arhipova, J. Donis, T. Gaitnieks, and I. Liepa, "Root and butt rot causing fungi: the impact of broadleaved species admixture on the indicence of Heterobasidion spp. in spruce stands". Mežzinātne 22 (55): 2010, pp.70-87.
[3] G. M. Bond, W. Fletcher, and Ferguson, T, "The development and function of the root nodules of Alnus, Myrica and Hippophae.” Plant Soil. 5, 1954, pp. 309-323.

[4] H.Claessens, L'aulne glutineux. Ses stations wet sa sylviculture. ASBL Fore Wallone, 2005, 189 p +2 annexes

[5] H. Claessens, A. Oosterbaan, and P. Savill, "A review of the characteristics of black alder (Alnus glutinosa (L) Gaertn.) and their implications for silvicultural practices”. Forestry, 2010, Vol, 83, No. 2

[6] H. Claessens, “The alder populations of Europe”. For. Comm. Bull. 126, 2003, pp. 5-14.

[7] T. Immler, T, "Waldbauliches Konzept zur Pflege der Schwarzerle. In Bayerische Landersanyalt fur Wald und Forstwirtschalf, Beitrage zur Schartzerle”. LWF Wissen 42, 2004, pp. 27-30.

[8] K. Korhonen and O.Holdenrieder, "Neue Erkenntnisse uber den Wurzelschwann *(Heterobasidion annosum s.l.) ”. Eine Literaturubersich. Forst and Holz 5: 2005, pp. 206-211.

[9] J.N. Koster, Die Wurzeln der Waldbaume. Paul Parey, Hamburg, Germany 1968,284p.

[10] K.W. Lockow, and S. Chizon, Diagnose des Roterlenkernfaule am stehenden Stamm. AFZ/Der Wald. 51, 1996, pp.1367-1371.

[11] V. Lygis, R. Vasiliauskas, J. Stenlid, and A.Vasiliauskas, "Silvicultural and pathological evaluation of Scots pine afforestations mixed with decidous trees to reduce the infection by Heterobasidion annosum s.s." Forest Ecology and Management, 201. 2004, pp. 275-285.

[12]Meža enciklopēdija. (Forest encyclopedia) 1.sējums. R.; apgāds "Zelta grauds" 2003. 368 lpp.

[13]V. N̦esterovs, Vispārīgā mežkopība. (General forestry). Latvijas Valsts izdevniecība. 1954, 610 lpp.

[14]T. Piri, K. Korhonen, and A. Sairanen, "Occurrence of Heterobasidion annosum in pure and mixed stands in southern Finland”. Scandinavian Journal of Forest Research 5: 1990, pp. 113-125. 
[15]C.M. Popovska and D. Ivanovski, "Disturbed river corridors and protection measures”. Balwois 27, 31 May Ohrid, Republic of Macedonia, 2008, pp. 1-7.

[16]N. Priedītis, "Black alder swamps on forested peatlands in Latvia.” Folia Geobotanica \&Phytotavonomica, 28, 1993, pp. 261-277.
[17]A.M. Thibaut and H. Claessens, Construction de tarifs de cubage d'arbres pour l'aulne glutineux (Alnus glutinosa L.Gaertn). 1998. Biotechnol. Agron. Soc. Environ. 2, 2003, 214 p.

[18]I. Vyhlidkova and D. Palovčikova, "Some aspects of alder decline along the Lužnice River”. Journal of Forest Science, 51, 2005, pp. 381-391. 